Masarykova univerzita, Brno

sramek@ped.muni.cz

\title{
SLOVOTVORBA A NÁZVOTVORBA
}

Klíč ová slova: teorie onomastiky, proprialita, propriální funkce, propriální sféra jazyka, tvoření vlastních jmen a tvoření obecných jmen

1. V každém vědeckém oboru se vyskytují situace, kdy určitý stupeň dosaženého poznání zkoumané materie a analyzovaných jevů nebo vztahů vyvolává potřebu vypracovat souhrn takových vlastností, znaků a funkcí, které jsou výsledkům bádání společné. Toho lze dosáhnout toliko interakcí dvou faktorů: vysokým stupněm abstrakce a na ni navazujícím zobecňováním. Základní vlastností této interakce je schopnost generalizujícího uplatnění v interpretační praxi. Proto musí výzkum i analýza konkrétní materie nebo problému být vždy překročeny směrem ke kategoriím obecného typu, tedy ke kategoriím obecného myšlení a poznání. Pouze ty jsou totiž cestou k poznání nikoli jen způsobů a forem vnějškové manifestace zkoumané materie, ale zároveň také těch jejích vnitřních vlastností, které ji spínají jako celek. Tyto vlastnosti ř́dí vznik, existenci a formy i funkce dané materie, a to nikoli nahodile a izolovaně, ale komplexně ve vzájemné podmíněnosti a komplementárnosti a především abstrahováním od roviny konkrétnosti studované matérie. Mají proto fundamentální účinek — postihují totiž systémovotvorné vlastnosti, a proto představují systém neboli systémové uspořádání daného celku. A nejen to. Jejich zobecňování se stává východiskem formulování teoretických i metodologických principů dané vědecké disciplíny. To v plné míre platí (nebo by mělo platit) také pro onomastiku.

Na její vývojové cestě jsou jasně zřetelné dvě orientace — materiálově a etymologicky interpretační, která se rozvíjela v duchu filologického pozitivismu mladogramatické školy a která v mnoha metodologických ohledech dosud přetrvává, a zaměření na problematiku obecně teoretického charakteru, tj. na pozici a funkce proprií $\mathrm{v}$ jazyce a komunikaci (Šrámek 1999). V onomastice se to projevilo nejprve v řešení vztahu apelativ a proprií, a to zvláště v interpretaci otázky „co znamená vlastní jméno“. Je to problém, který je v onomastice od počátku jejího vzniku jako vědecké disciplíny stále př́tomen. Odpověd’ na tuto otázku, která v sobě už od dob Millových (Mill 1841) zahrnuje $\mathrm{v}$ různé podobě zřetele jazykové i mimojazykové (u Milla napřs. také argumenty logiky), se nezř́íka stává charakteristickým znakem onomastických škol. 
V polovině minulého století, kdy se do pracovního pole onomastiky dostávaly ale jen velmi skromně a ojediněle — některé principy moderní lingvistiky, a to na prvním místě kategorie „struktura“ a „,unkce“, nabyl výzkum postavení a funkce proprií v jazyce povahy dvou teoreticky odlišných pojetí. „Lingvistický status“ proprií, pod který J. Kuryłowicz $(1956,1980)$ široce subsumoval propria díky tomu, že za jejich typologicky základní vlastnost vyzdvihl jejich ,jazykovost“, významně rozšíril V. Blanár $(1969,1976)$ o „status onomastický“ zaměřený na obecné a systémové vlastnosti proprií uvnitř jazyka především z hlediska jejich komunikačních funkcí a strukturních hodnot. Bylo tak podtrženo to, co je na propriích nejen „lingvistické“, ale především „specificky onomastickéc“.

2. Obecná teorie onomastiky se stala integrální součástí onomastiky jako vědecké disciplíny, jako subdisciplíny lingvistiky s velkou mírou autonomnosti (Šrámek 1999: 16, 50-51; Pleskalová 2002: 293). Teoretická bádání dosáhla pozoruhodných výsledků, které proměňují dosavadní tradiční názory na podstatu, obsah a smysl onomastiky vůbec. Byla např. formulována koncepce propriální sféry jazyka, komunikačního zakotvení motivické a sémantické specifičnosti proprií, koncepce systémotvorného charakteru propriálně pojmenovacího aktu jako sémanticky specifické interakce zřetele komunikačního, objektového, pojmenovacího a funkčního. A právě specifičnost této interakce vyvolává nutnost v propriální sféře jazyka (čili také v onomastice vůbec) mluvit o názvotvorbě, nikoli o jen slovotvorbě.

Onomastika na vysoce abstrahované úrovni obohacuje obecnou lingvistiku tím, že v systematice a funkcích jazyka vidí dvě sféry jeho existence - apelativní a propriální. Zdůrazňujeme, že mezi nimi nejde o vztah absolutní opozice, ale o vztah vzájemně prostupný různými typy vazeb; to z hlediska lexikologického a sémiotického přesvědčivě potvrzuje i např. W. van Langendonck (2007). Tato prostupnost umožňuje vznik obousměrné fundace, což je základní okolnost, která v rámci struktur a systémů jazyka umožňuje koexistenci jeho apelativní a propriální sféry (o tom viz ještě na konci stati). Vztah „,slovotvorba“_—,názvotvorba“ je tohoto instruktivním př́kladem.

K objasnění tohoto vztahu je však z hlediska onomastiky třeba vzít v úvahu nejméně tři důležité podmínky, totiž:

a) zkušenost ve strukturní (morfémové) analýze a typologii jazykové formy proprií, která však není omezená jen na problematiku etymologické rekonstrukce;

b) poznatky z lexikologie týkající se zvláště:

- mechanismu tvorby lexémů, zejména jejich morfémové struktury,

- repertoáru, frekvence a produktivity slovotvorných způsobů, tj. především derivace a kompozice včetně využití metafor nebo metonymií,

— úlohy sémantiky, zvláště vztahu lexikálně sémantického významu apelativ a sémantického obsahu propriálně pojmenovacího motivu;

c) spolehlivá orientace ve specifické podstatě, systematice a funkcích propriální sféry jazyka. 
3. Jak současná publikační produkce onomastiky (a slovanskou nevyjímaje) ukazuje, prosazují se $\mathrm{v}$ ní zřetele $\mathrm{k}$ výsledkům bádání $\mathrm{v}$ oblasti obecných teoretických východisek a principů jen pomalu a nerovnoměrným způsobem. To má nežrídka za následek, že hlavní pole vědeckého zájmu o jazyk je orientováno především (nebo dokonce pouze) na apelativní sféru jazyka a že onomastice je stále přisuzován charakter interdisciplinárního oboru materiálového, popř. etymologického zaměření, což vede k apelativistickému pojetí proprií. Ve vztahu kategorií „slovotvorba“ $\leftrightarrow$ „názvotvorba" se toto stanovisko projevuje tak, že se v gramatických popisech jazyka způsoby tvoření proprií mechanicky subsumují regulím slovotvorby apelativ, ale i obráceně, totiž tak, že práce onomastické při analýze a klasifikaci morfematických struktur a funkcí proprií pomíjejí specifičnost onymie. A tak se s onomasticky teoretickou analýzou podstaty kategorie „názvotvorba“ setkáváme v onomasticky teoretických pracích nebo encyklopediích jen zcela sporadicky. Termínu názvotvorba se v současné onomastice sice — nikoli však systematicky — užívá, ale z kontextu jeho užití není vždy jasné, zda se vlastně jen synonymně nepojmenovává „slovotvorba“. Tak rejstř́k impozantní mezinárodní onomastické encyklopedie (HSK: 1922) nemá obecné definiční heslo Namenbildung, ale jen odkazy na konkrétnosti (Namenbildung/ Familiennamen, - mechanische, - primäre, - rationale, - sekundäre). Podobně nemají definici Namenbildung ani vynikající príručky o pracovních metodách v onomastice (A. Brendler, S. Brendler 2004; Ziegler, Windberger-Heidenkummer 2011). $\mathrm{O}$ to větší je zásluha $\mathrm{H}$. Borka, který se v řadě studií problematice „nazwotwórstwa“ soustavně věnoval (viz zejména Borek 1984).

Z výše řečeného vyplývá, že pokládáme proto za nutné vyzvednout nejprve ty základní charakteristiky propriální sféry jazyka, které ve vztahu kategorií „slovotvorba“ a „názvotvorba“ mají principiální, systémotvorný a propriálně specifikující význam.

Nejobecnější znaky, které ve struktuře a systematice jazyka spínají jeho propriální sféru ${ }^{1}$ jako celek a tím ji diferencují od sféry apelativní, jsou tři.

\subsection{Kategorie "proprialita“}

Má dva rozměry: a) Proprialita obecná

Všechny prvky, elementy, vztahy, regule, které $\mathrm{v}$ rámci jazyka vytváŕejí celek (útvar) ,propriální sféra jazyka“, jsou vždy nositeli př́iznaku „proprialita“. Znamená to, že všechny elementy funkčně působí a musí působit jedním směrem, tj. směrem propriálním. Protože tento příznak je na základě principu obecného a zvláštního společný jak všem elementům propriální sféry, tak této sfére jako celku, má společný př́znak rozměr kategorie „obecné propriality“. Znamená to, že propriálním směrem působí (musí působit) i elementy jazykové stránky proprií. A zde jsme u kořene

${ }^{1}$ K jejímu konstituování, definování a k jejím funkcím viz Šrámek1991: 13-78, souhrnně ve studiích v Šrámek 2007; k jejímu vývojovému dynamismu Šrámek 2011; ke kategorii 'propriální pojmenovací akt' viz polsky Šrámek 1986. 
otázky, jak jazykové elementy propriální sféry jazyka lingvisticky, tj. především funkčně interpretovat. Jsou tyto elementy slovotvorné, nebo názvotvorné? Jestliže však nějaký element jazykový i nejazykový (např. objekt, motiv) není nositelem obecné propriality, nemůže být funkčním prvkem propriální sféry jazyka. Z toho vyplývá, že aby nějaký element mohl být inkorporován do propriální sféry jazyka (např. propriálně sémanticky motivující lexém (lípa, náklo, mokrý, Bohuslav atd.), slovotvorný formant (-isko, -árna, -ek, -jb atd.) nebo slovotvorný princip (kompozice, deminutivizace, substantivizace, syntagmatické spojení mokrý atd.)), musí nabýt a nést př́znak obecné popriality, tj. musít mít schopnost „být nebo vytvářet vlastní jméno“. Neboli: musí se funkčně realizovat jako prvek propriální sféry jazyka. Obecná proprialita externě odlišuje propria od apelativ, a proto i „názvotvorbu“ od apelativní „slovotvorby“.

b) Proprialita specifikující

Prostor její realizace je vymezen interní strukturou a systematikou propriální sféry jazyka. Směr jejího působení je tedy interní. Podstata základního dělení onymie na tř́idy bionym, geonym a chrématonym neleží na jazykové stránce proprií, ale na systematice onymických objektů, jichž se propria jako jazykové znaky sui generis týkají2. První krok je, že objekt, který má být z příčin mimojazykových (komunikačních, společenských) identifikován jako jednotlivina, je včleněn do objektového rámce propriální sféry jazyka. Tím je obdařen př́znakem individuálnosti, tj. faktorem obecné propriality, a je vřazen do tř́dy onymických objektů stejného druhu, což je výrazem uplatnění propriality specifikující.

Každé proprium je vlastním jménem jen tehdy, nese-li v sobě nedělitelnou jednotu propriality obecné a specifikující. Nositelem obou faktorů je onymický objekt. Př́íklad:

Lexém Kraków: a) je vlastní jméno, nikoli apelativum. Tento status je výsledkem uplatnění obecné propriality. V komunikaci plní propriální funkce. b) V onymii, v propriální sféře i v komunikaci má hodnotu oikonyma, tj. poddruhu toponym, tedy geonym. Proto není Kraków antroponymem, ale oikonymem. Je to výsledek uplatnění propriality specifikující.

Kombinace propriality obecné a specifikující je podstatou i obsahem propriálně systémotvorné kategorie, která není identická s jazykovým mechanismem lexikální nominace. Nazvat ji lze „propriální hodnota propriálního lexému“满. Vyjádřit ji můžeme např. takto modelově:

${ }^{2}$ Podrobnější zdůvodnění viz Šrámek 1999: 11-14; 2007: 241-250 (= přetisk stati Šrámek 1981: 503-511). Významnou studii k problematice onymických objektů napsala E. Windberger-Heidenkummer (2011: 29-46).

3 Tuto myšlenku nebudeme $\mathrm{v}$ této stati dále rozvíjet. Teprve další výzkum v teorii onomastiky ukáže, zda je smysluplná. Máme na mysli např. toto: Jaká je pozice literární onomastiky (tedy její propriální hodnota) v propriální sféře jazyka? Je prop/lit (podobně jako prop/oiko), nebo prop/chrém subtyp lit.? 


\begin{tabular}{|c|c|c|}
\hline Lexém Kraków & proprialita + oikonymičnost & prop/oiko \\
\hline Lexém Barbara & proprialita + antroponymičnost & prop/antropo \\
\hline Lexém Basia & proprialita + hypokorističnost & prop/hypokor \\
\hline Lexém Odra (řeka) & proprialita + hydronymičnost & prop/hydı \\
\hline Lexém Odra (hotel) & proprialita + chrématonymičnost & \\
\hline
\end{tabular}

V prŕpadech transonymizace 4 typu Odra, řeka' $>$ Odra, hotel' je zřetelně vidět hodnotovou podstatu propriálně názvotvorného procesu, poněvadž chrématonymum vzniklo transonymizací hydronyma: prop/hydro $\rightarrow$ prop/chrém. Avšak rozdílnost propriálních hodnot zůstává často nepovšimnuta a může vést $\mathrm{k}$ chybné interpretaci propriálně pojmenovacího procesu, jak ukazuje tento př́íklad výkladu propria Bystřice:

Hydronymum Bystřice (pol. Bystrzyca, sloven. Bystrica atd.):

- slovotvorně: bystr- + -ica = ,bystrá voda' (tj. bystře tekoucí);

— názvotvorně: substantivizace adj. bystrá v syntagmatu bystrá voda.

S apelativní slovotvorbou pouhá homonymie. Názvotvorný akt pro jedinečný objekt. Propriální význam: „konkrétní řeka s konkrétní lokalizací“. Podobně něm. Wildbach:

— propriální hodnota: prop/hydro.

Oikonymum lokality Bystřice založené na řece Bystřici:

— slovotvorně: při vzniku oikonyma se neuplatňuje;

— názvotvorně: bezsufixální transonymizace hydronyma;

— propriální hodnota: prop/hydro > prop/topo, subtyp prop/oiko.

Jen okrajově se zmiňujeme o tom, že mohou nastat př́pady, kdy transonymizace je spojena s uplatněním různých toponymických formantů. Zvýší se tím zřetelnost identifikační diference mezi fundujícím a fundovaným propriem. Tato problematika není v teoretickém popisu transonymizace dosud podrobněji propracována. Např.:

Oikonymicky (,sufixálně“) fungující pluralizace:

řeky Odra, Svitava $\rightarrow$ města Odry, Svitavy

Oikonymicky deminutivní sufixace:

řeky Dyje, Jihlava, Svitava $\rightarrow$ vsi Dyjice, Jihlávka, Svitávka

3.2. Kategorie „propriální význam“

Pro účely našeho příspěvku postačí, řekneme-li, že význam propria není vymezen lexikálně sémantickým významem základního (výchozího) apelativa nebo me-

${ }^{4}$ O ní viz blíže: Cieślikowa 1994; Šrámek 2004; Tušková 2011. Jako metodologický prvek onomastických analýz je využívána spíše řidčeji. Pracují s ní např. M. Biolik (2014: 198-199), R. Mrózek (1990). 
taforického vyjádření propriálného motivu. Např. prríjmení Borek neznamená „malý bor“, příjm. Vrba neznamená „vrba“, ale „bydlící u vrby“, „mající nezvykle dlouhé vlasy“"5. Proto není možné na základě tisíců proprií Borek, Vrba provést zobecnění do pojmového významu „malá borovice“, „malá vrba“ a není ani možné proprium přeložit. V cizojazyčném, např. německém kontextu nelze prof. Henryka Borka nazvat Heinrich Wäldchen, Heinrich Kieferchen. Proprium by ztratilo identifikační, individualizující, diferencující funkci. V komunikaci by ztratilo propriální hodnotu, nebot' jeho deapelativní část (Borek) by se nelišila od motivujícího apelativa (bo$r e k$ ). Proprium by bylo interpretováno apelativně, nikoli názvotvorně.

Propriální význam je vždy prostřednictvím pojmenovacího motivu svázán s propriálním objektem, a to s objektem jako jednotlivinou. Vzniká totiž na základě individualizující funkce propria, která je vždy spojena s plnou desémantizací základního motivujícího apelativa. Př́ijmení Borek v kombinaci s rodným jménem Henryk propriálně znamená „,vynikající polský onomastik, profesor v Opolí, autor monografie o oikonymech s -bn-, prř́jemný člověk, bohužel předčasně zemřelý““. S propriálním významem nepracuje slovotvorba, ale názvotvorba. Je podmínkou existence propria v komunikaci.

\subsection{Kategorie „fundace“}

Jak jsme ukázali, proprialita se nekryje, nemůže se krýt s apelativitou, z čehož vyplývá, že se apelativní sféra jazyka různí od sféry propriální. Obě sféry však v jazyce i komunikaci vždy koexistují spolu, a tím spoluvytvářejí základní sít' neboli strukturní celistvost jazyka vůbec. Zásadní je však otázka, jaký mezi oběma sférami existuje vztah, jak se k sobě navzájem chovají. Obecná onomastická teorie tento vztah vzájemné součinnosti definuje jako „fundace“ a určuje dva její typy, které se navzájem liši směrem působení:

a) proprializace ${ }^{6}$ prvků apelativní sféry: borek $>$ př́ijmení Borek. Modelově: $\mathrm{A} \rightarrow \mathrm{P}$

b) apelativizace prvků propriální sféry: lékař Roentgen > prŕstroj rentgen: $\mathrm{P} \rightarrow \mathrm{A}$.

Fundace se jako názvoslovný způsob uplatňuje i interně v propriální sféře jazyka, nejvýrazněji při tvoření propria transonymizací (viz výše). Modelově: $\mathrm{P} \rightarrow \mathrm{P}^{7}$.

Pro onymii každého jazyka má fundace typu $\mathrm{A} \rightarrow \mathrm{P}$ př́mo existenční význam. Apelativní sféra je totiž pro propriální sféru pramenem formálních a lexikálních (jazykových) prostředků k realizaci propriálních názvotvorných aktů. Vedle prostředků formálních, jako jsou etymony, lexémy, morfémy, sufixy atd., poskytuje apelativní

\footnotetext{
${ }^{5}$ Srov. přirovnání z čes. slezských nářečí: ma dtuhe vłasy jak vyrba.

${ }^{6}$ Vyskytuje se též synonymní termín onymizace.

${ }^{7}$ Této problematice se $\mathrm{v}$ naší stati nevěnujeme. V odborné literatuře se $\mathrm{k}$ tomu najdou rozdílná řešení.
} 
sféra také pravidla tvoření slov, kompozit, deminutiv, metonymií, syntagmat a modely struktur apod. A co je hlavní, apelativní sféra vytváří komunikační médium, ve kterém se propriální sféra realizuje. Propriální sféra sama o sobě totiž ze sémantických a funkčních důvodů jazykové komunikační médium vytvořit nemůže, protože její podstatou není predikování, ale specifický typ nominace. Z této specifičnosti propriální nominace vyplývá, že se fundování typu $\mathrm{A} \rightarrow \mathrm{P}$ neděje mechanicky, ale vždy s ohledem na nutnost a schopnost vyjádřit propriálně relevanci názvoslovného aktu. Fundování apelativní sférou má proto charakter selekce, pro kterou je typická vysoká míra potenciálnosti. Apelativní systémy nabývají v procesu fundace charakter parasystémů (tj. neúplnosti; viz Pleskalová 2000, Šlosar 2010), v propriální sféře nabývají příznaku propriality, a tím se stávají složkami názvotvorby. Této funkční a systémotvorné proměny si slovotvorná interpretace proprií nevšímá a řadí názvotvorné způsoby a prostředky pod kritéria apelativní. Př́ímení Borek a apelativum borek splynou typem tvoření vjedno.

Na pozadí vztahu ,słowotwórstwo onomastyczne“ a ,słowotwórstwo gwarowe“ tuto okolnost přesně vystihl S. Gala. Užívá sice termínu „słowotwórstwo“, ale z kontextu vyplývá, že má na mysli „,nazwotwórstwo“:

Różne funkcje obu kategorii znaków językowych (tj. apelativních a propriálních, RŠ) i różne ich miejsce w systemie wpłynęły na wytworzenie się z czasem autonomicznych w onomastyce zasad derywacyjnych [...] Ogólne zasady derywacji apelatywnej v polszczyźnie ogólnej w odniesieniu do nazw własnych mają zakres ograniczony, tak jak lokalny, regionalny charakter wykazują nazwy własne (Gala 2003: 59).

To, co Gala formuluje pro vztah onymie a dialektu, má platnost obecnou. Rozměr a fundace typu $\mathrm{A} \rightarrow \mathrm{P}$ se vždy realizují podle typologických vlastností daného jazyka a podle komunikačních potřeb.

\section{Závěr}

Slovotvorba je i v onomastice složkou jejích teoretických principů a metodologických postupů i lexikologických analýz. Její pohled je však zúžen na povrchovou rovinu proprií, tj. na jejich ,jazykovost". Slovotvorba popisuje povrchové struktury jazykové stránky proprií. Názvotvorba analyzuje propriálně pojmenovací proces, studuje vznik propria jako specifického nominačního a sémiotického znaku. Názvotvorba není součástí apelativní slovotvorby. Principy slovotvorby sice platí i pro propria, ale v propriální sféře se realizují v potenciálním výběru, vždy však musí mít př́znak propriality. Názvotvorba je druh specifické nominace s obligatorní prítomností exponentu propriality. Jinak nevznikne proprium. 


\section{BIBLIOGRAFIE}

Biolik M. 2014: Uwagi o zbieraniu i budowie nazw terenowych, [v:] A. Gałkowski, R. Gliwa (red.), Mikrotoponimia i makrotoponimia. Problematyka wstęnna. Microtoponymy and Macrotoponymy. Preliminary Problems, Wyd. UŁ, Łódź, s. 195-205.

Blanár V. 1969: Das spezifisch Onomastische, [v:] H. u. H. Hornung (Hrsg.): Disputationes ad monitum vocabula nominum aliorumque significationes pertinentes, Verl. der Wiener Medizinischen Akademie, Wien, s. 81-87.

Blanár V. 1976: Lingvistický a onomastický status vlastného mena, „Onomastica“ XXI, s. 5-18.

Borek H. 1984: Z problematyki nazwotwórstwa toponimicznego, „Zeszyty Naukowe WSP w Opolu. Językoznawstwo“ IX, s. 57-62.

Brendler A., Brendler S. (eds.) 2004: Namenarten und ihre Erforschung. Ein Lehrbuch für das Studium der Onomastik. Anlässlich des 70. Geburtstages von Karlheinz Hengst, baar, Hamburg.

Cieślikowa A. 1994: O motywacji w onomastyce, „Polonica“ XVI, s. 193-199.

Gala S. 2003: Słowotwórstwo onomastyczne i słowotwórstwo gwarowe, [v:] M. Biolik (red.), Metodologia badań onomastycznych, Ośrodek Badań Naukowych im. W. Kętrzyńskiego, Olsztyn, s. 58-62.

HSK - Eichler E. a kol. (eds.), Namenforschung - Name Studies - Les noms propres. Ein internationales Handbuch zur Onomastik. An International Handbook of Onomastics. Manual international d'onomastique, Walter de Gruyter, Berlin-New York, 1. Bd. 1995, 2. Bd. 1996, 3. Bd. 1996.

Kuryłowicz J. 1956: La position linguistique du nom propre, „Onomastica“ II, s. 1-4.

Kuryłowicz J. 1980: The Linguistic Status of Proper Nouns (Names), „Onomastica“ XXV, s. 5-10.

Langendonck W. van 2007: Theory and Typology of Proper Names, Mouton de Gruyter, Berlin-New York.

Mill J. S. 1841: A System of Logic. Ratiosinative and Inductive: Being and connected view of the principles of evidence and the method of scientific investigation, I-II, Longmans, London.

Mrózek R. 1990: System mikrotoponimiczny Ślaska Cieszyńskiego XVIII wieku, UŚ, Katowice.

Pleskalová J. 2000: O tzv. parasystému, „Sborník prací Filozofické fakulty brněnské univerzity“, ř. A48, s. $41-46$.

Pleskalová, J. 2002: Onomastika, [v:] P. Karlík, M. Nekula, J. Pleskalová (eds.), Encyklopedický slovník češtiny, Nakladatelství Lidové noviny, Praha.

Šlosar D. 2010: Utvářenost slov vstupujících do pomístních jmen na Moravě a ve Slezsku, „Acta onomastica“ LI, č. 1, s. 314-338.

Šrámek R. 1981: Das onymische und das appellativische Objekt, [v:] Rymut K. (ed.), Proceedings of the XIII ${ }^{\text {th }}$ International Congress of Onomastic Sciences, Ossolineum, Wrocław, vol. II, s. 503-511 .

Šrámek R. 1988: Teoria onomastyki i płaszczyzny nominacji proprialnej, „Zeszyty Naukowe WSP w Opolu. Językoznawstwo“ XI, s. 19-34.

Šrámek R. 1991: Die appellativische und die propriale Sprachsphäre, „Österreichische Namenforschung“ 19, s. 73-78.

Šrámek R. 1999: Úvod do obecné onomastiky, Masarykova univerzita, Brno.

Šrámek R. 2004: Transonymizace v propriální nominaci, „Folia onomastica Croatica“ 12-13, s. 499-508 .

Šrámek R. 2007: Beiträge zur allgemeinen Namenkunde, hrsg. v. E. Hansack, Praesens Verl., Wien.

Šrámek R. 2013: Dynamismus propriální sféry jazyka, [v:] E. Dzięgiel, T. Korpysz (red.), Niejedno ma imię... Prace onomastyczne $i$ dialektologiczne dedykowane Profesor Ewie Wolnicz-Pawłowskiej, Wyd. UKSW, Warszawa.

Tušková J. 2011: Transonymizace a chrématonyma, [v:] M. Biolik, J. Duma (red.), Chrematonimia jako fenomen współczesności, Wyd. UWM, Olsztyn, s. 485-491. 
Windberger-Heidenkummer E. 2011: Onymische Monovalenz und Klassenbildung. Ein onomastisches Problem und seine methodischen Folge, [v:] A. Ziegler, E. Windberger-Heidenkummer (Hrsg.), Methoden der Namenforschung. Methodologie, Methoden und Praxis, Akademie Verl., Berlin, s. 29-46.

Ziegler A., Winberger-Heidenkummer E. (Hrsg.) 2011: Methoden der Namenforschung. Methodologie, Methoden und Praxis, Akademie Verl., Berlin.

\section{FORMATION OF COMMON NAMES AND PROPER NAMES}

\section{SUMMARY}

Within onomastics, the formation of common names constitutes a part of interpretation procedures and lexicological analyses. Its perspective, however, is narrowed down to the language level of propria, i.e. to their superficial structure. The formation of proper names analyses the naming process, and investigates the formation of the proprium as specific nominative and semiotic characteristics. The principles of the formation of common names are also applicable to the principles of the formation of proper names, in which case, however, they always must be subject to a proprial purpose. Otherwise, a proper name cannot be created. The elements of common name formation are reflected in the proprial domain of language in a parasystematic way, i.e. in the potential selection. The key categories differentiating the formation of proprial names from the formation of common names are as follows: a) propriality (both generic and systemic) that results in the "proprial value of the lexeme" and creation of transonymisation, b) proprial meaning that is always linked to a proprial subject and proprial function, c) apel $\leftrightarrow$ prop fundation in form of either appelativisation or proprialisation. The formation of common names is subject to predication whereas the formation of proper names is subject to a specific type of nomination. More enhanced theoretical research is needed to define a precise terminological specification.

K ey w ord s: theory of onomastics, propriality, proprial function, proprial sphere of language, formation of proper names and formation of common names 